\title{
ANALISIS EFEK KECELAKAAN WATER INGRESS TERHADAP REAKTIVITAS DOPPLER TERAS RGTT200K
}

\author{
Zuhair, Suwoto \\ Pusat Teknologi dan Keselamatan Reaktor Nuklir - BATAN \\ Kawasan Puspiptek, Gedung No. 80, Serpong, Tangerang 15310 \\ Tel. (021)756-0912, Fax. (021)756-0913, E-mail: zuhairbasjmeleh@yahoo.com \\ Diterima editor: 15 Januari 2015 \\ Direvisi editor: 29 Januari 2015 \\ Disetujui untuk publikasi: 4 Februari 2015
}

\begin{abstract}
ABSTRAK
ANALISIS EFEK KECELAKAAN WATER INGRESS TERHADAP REAKTIVITAS DOPPLER TERAS RGTT200K. Dalam high temperature reactor, koefisien reaktivitas temperatur yang didesain negatif menjamin reaksi fisi dalam teras tetap berada di bawah kendali dan panas peluruhan tidak akan pernah melelehkan bahan bakar yang menyebabkan terlepasnya zat radioaktif ke lingkungan. Namun masuknya air (water ingress) ke dalam teras reaktor akibat pecahnya tabung penukar panas generator uap, yang dikenal sebagai salah satu kecelakaan dasar desain, dapat mengintroduksi reaktivitas positif dengan potensi bahaya lainnya seperti korosi grafit dan kerusakan material struktur reflektor. Makalah ini akan menganalisis efek kecelakaan water ingress terhadap reaktivitas Doppler teras RGTT200K. Kapabilitas koefisien reaktivitas Doppler untuk mengkompensasi reaktivitas positif yang timbul selama kecelakaan water ingress akan diuji melalui serangkaian perhitungan dengan program MCNPX dan pustaka ENDF/B-VII untuk perubahan temperatur bahan bakar dari $800 \mathrm{~K}$ hingga $1800 \mathrm{~K}$. Tiga opsi kernel bahan bakar $\mathrm{UO}_{2}$, $\mathrm{ThO}_{2} / \mathrm{UO}_{2}$ dan $\mathrm{PuO}_{2}$ dengan tiga model kisi bahan bakar pebble di teras reaktor diterapkan untuk kondisi water ingress dengan densitas air dari 0 hingga $1.000 \mathrm{~kg} / \mathrm{m}^{3}$. Hasil perhitungan memperlihatkan koefisien reaktivitas Doppler tetap negatif untuk seluruh opsi bahan bakar yang dipertimbangkan bahkan untuk posibilitas water ingress yang besar. Efek water ingress lebih kuat pada model kisi dengan fraksi packing lebih rendah karena lebih banyak volume yang tersedia untuk air yang memasuki teras reaktor. Efek water ingress juga lebih kuat di teras uranium dibandingkan teras thorium dan plutonium sebagai konsekuensi dari fenomena Doppler dimana absorpsi neutron di daerah resonansi ${ }^{238} \mathrm{U}$ lebih besar daripada ${ }^{232} \mathrm{Th}$ dan ${ }^{240} \mathrm{Pu}$. Secara keseluruhan dapat disimpulkan bahwa, koefisien Doppler teras RGTT200K mampu mengkompensasi insersi reaktivitas yang diintroduksi oleh kecelakaan water ingress. Teras RGTT200K dengan bahan bakar $\mathrm{UO}_{2}, \mathrm{ThO}_{2} / \mathrm{UO}_{2}$ dan $\mathrm{PuO}_{2}$ dapat mempertahankan fitur keselamatan melekat dengan cara pasif.
\end{abstract}

Kata kunci: Water ingress, reaktivitas Doppler, RGTT200K

\section{ABSTRACT}

ANALYSIS OF THE EFFECT OF WATER INGRESS ACCIDENT ON DOPPLER REACTIVITY OF RGTT200K CORE. In high temperature reactor, the negative temperature reactivity coefficient guarantees fission reaction in the core remain under the control and decay heat will not melt the fuel which cause the release of radioactive substances into the environment. But the entry of water (water ingress) into the reactor core due to rupture of a steam generator tube heat exchanger, which is known as one of the design basis accidents, can introduce positive reactivity with other potential hazards such as graphite corrosion and damage of the reflector structure material. This paper will investigate the effect of water ingress accident on Doppler reactivity coefficient of RGTT200K core. The capability of the Doppler reactivity coefficient to compensate positive reactivity incurred during water ingress accident will be examined through a series of calculations with MCNPX code and ENDF/B-VII library for fuel temperature changes from $800 \mathrm{~K}$ to $1800 \mathrm{~K}$. Three options of $\mathrm{UO}_{2}, \mathrm{ThO}_{2} / \mathrm{UO}_{2}$ and $\mathrm{PuO}_{2}$ fuel kernels with three lattice models of fuel pebble in the reactor core was applied for condition of water ingress with water density from 0 to $1000 \mathrm{~kg} / \mathrm{m}^{3}$. The results of the calculations show that Doppler reactivity coefficient is negative for the entire fuel options being considered even for a large possibility of water ingress. The effects of water ingress becomes stronger in lattice model with lower packing fraction because more volume available for water entering the reactor core. The effect of water ingress is also stronger in the uranium core compared to thorium and plutonium cores as a consequence of the Doppler phenomenon where the neutron absorption in resonance region of ${ }^{238} U$ is greater than ${ }^{232} \mathrm{Th}$ and ${ }^{240} \mathrm{Pu}$. It can be concluded overall that Doppler coefficient of RGTT200K core has capability to compensate the reactivity insertion introduced by water ingress accident. RGTT200K core with $\mathrm{UO}_{2}, \mathrm{ThO}_{2} / \mathrm{UO}_{2}$ and $\mathrm{PuO}_{2}$ fuels can maintain the inherently safety features in a passive way.

Keywords: Water ingress, Doppler reactivity, RGTT200K 


\section{PENDAHULUAN}

Permintaan energi dunia meningkat secara dramatis dalam beberapa dekade terakhir ini. Populasi dunia dalam 50 tahun ke depan akan bertambah dari 6 ke 9 milyar dan konsumsi energi diprediksi tumbuh pesat seiring dengan meningkatnya kebutuhan kualitas hidup yang lebih baik. Energi nuklir menjadi faktor kunci dalam memastikan pasokan energi bersih, aman dan berkelanjutan di masa mendatang. Namun isu keselamatan selalu menjadi perhatian utama dalam industri tenaga nuklir. Insiden Fukushima yang mengejutkan dunia dengan dampaknya memperjelas jika energi nuklir akan memainkan peranan utama dalam pemenuhan kebutuhan energi dunia, sifat keselamatan melekat (inherently safety) dan ramah lingkungan yang dimiliki reaktor nuklir menjadi syarat mutlak [1].

Reaktor Generasi IV merupakan seperangkat desain reaktor teoretik yang saat ini sedang dikembangkan di 13 negara dalam elaborasi Forum Internasional Generasi IV (Generation IV international forum, GIF) [2] dengan tujuan utama meningkatkan keselamatan nuklir dan resistansi proliferasi. Tujuan GIF lainnya adalah meminimalkan limbah dan memaksimalkan pemanfaatan sumber daya alam serta mengurangi biaya konstruksi dan pengoperasian reaktor. Reaktor temperatur tinggi (high temperature reactor, HTR) menjadi salah satu jenis dari enam desain reaktor Generasi IV yang menggunakan moderator grafit, pendingin helium dan beroperasi pada temperatur sangat tinggi $\left(\sim 1000^{\circ} \mathrm{C}\right)$. Desain HTR terdiri dari teras reaktor yang dikelilingi oleh reflektor aksial dan reflektor radial. Geometri teras HTR dapat berupa blok prismatik seperti reaktor uji temperatur tinggi (high temperature test reactor, HTTR) Jepang [3] atau pebble bed seperti HTR-10 Cina [4]. Kedua jenis HTR ini menggunakan bahan bakar yang berasal dari unsur grafit dan material fisil dalam bentuk partikel TRISO. Kualitas partikel TRISO yang luar biasa dari resistansi dan retensi produk fisi menjadi inovasi fundamental dalam bidang teknologi keselamatan HTR yang intrinsik.

Salah satu karakteristik keselamatan melekat dalam HTR adalah koefisien reaktivitas temperatur yang negatif dan kapasitas panas tinggi dari struktur teras yang dapat mencegah bahan bakar dari kenaikan temperatur melebihi $1600^{\circ} \mathrm{C}$. Koefisien reaktivitas negatif HTR menjamin reaksi fisi dalam teras tetap berada di bawah kendali dan panas peluruhan tidak akan pernah melelehkan bahan bakar sehingga mencegah terlepasnya zat radioaktif ke lingkungan. Namun masuknya air (water ingress) ke dalam teras reaktor akibat pecahnya tabung penukar panas generator uap, yang dikenal sebagai salah satu kecelakaan dasar desain (design basic accident, DBA), akan mengintroduksi reaktivitas positif dengan potensi bahaya lainnya seperti korosi grafit dan kerusakan material struktur reflektor.

RGTT200K adalah reaktor temperatur tinggi bertipe pebble bed dengan daya termal $200 \mathrm{MW}$ yang didesain untuk menghasilkan listrik dan aplikasi panas proses berbagai industri seperti produksi hidrogen, desalinasi air laut. Selain siklus langsung, RGTT200K mempertimbangkan siklus tak langsung dengan turbin uap yang teknologinya sudah berkembang. Akan tetapi penggunaan turbin uap memungkinkan terjadinya kecelakaan water ingress. Hasil studi sebelumnya mendemonstrasikan RGTT200K dapat didesain dengan koefisien reaktivitas negatif [5] dan analisis water ingress di teras RGTT200K juga telah dilakukan dengan kesimpulan perubahan reaktivitas positif terjadi untuk teras dengan bahan bakar pebble mengandung lebih dari 10.000 partikel TRISO per pebble [6]. Karena bahan bakar pebble RGTT200K mengandung 15.000 partikel TRISO per pebble, maka kemampuan koefisien reaktivitas negatif bahan bakar, yang disebut reaktivitas Doppler, untuk mengkompensasi reaktivitas positif yang timbul selama kecelakaan water ingress perlu diuji untuk meyakinkan reaktor tetap memliliki sifat keselamatan melekat. Makalah ini akan menganalisis efek kecelakaan water ingress terhadap reaktivitas Doppler teras RGTT200K. Identifikasi reaktivitas Doppler dilakukan melalui serangkaian perhitungan dengan program transport Monte Carlo MCNPX [7] dan pustaka data nuklir energi kontinu ENDF/B-VII [8] pada temperatur bahan bakar dari $800 \mathrm{~K}$ hingga $1800 \mathrm{~K}$. Tiga opsi kernel bahan bakar $\mathrm{UO}_{2}, \mathrm{ThO}_{2} / \mathrm{UO}_{2}$ dan $\mathrm{PuO}_{2}$ dengan tiga model kisi bahan bakar pebble di teras reaktor diterapkan untuk kondisi water ingress dengan densitas air dari 0 hingga $1000 \mathrm{~kg} / \mathrm{m}^{3}$. Hasil analisis diharapkan dapat menunjukkan seberapa besar efek water ingress terhadap reaktivitas Doppler teras RTT200K dengan berbagai opsi bahan bakar. 


\section{DESKRIPSI SINGKAT RGTT200K}

RGTT200K terdiri dari teras silinder dengan tinggi $943 \mathrm{~cm}$ dan diameter $300 \mathrm{~cm}$ yang dikelilingi oleh refektor grafit radial dengan ketebalan $200 \mathrm{~cm}$ dan reflektor grafit aksial dengan ketebalan total $750 \mathrm{~cm}$. Helium dipilih sebagai pendingin teras reaktor karena memiliki beberapa keuntungan. Selain secara kimia inert, helium tidak mudah terbakar atau korosif yang berarti tidak diperlukan pemeliharaan untuk mengatasi kerusakan material jika melakukan kontak dengan gas. Helium juga transparan sehingga kerusakan yang mungkin dari sistem dapat dilihat dengan lebih mudah. Tampang lintang absorpsi helium yang rendah sangat baik untuk reaksi pembiakan (breeding) dan moderasinya yang rendah menghasilkan spektrum yang lebih keras. Spektrum keras bermanfaat untuk breeding dan pemuatan aktinida minor sebagai bahan bakar reaktor. Helium juga memiliki efek reaktivitas pendingin yang kecil, baik temperatur maupun void dan karena helium pendingin non radioaktif, penggunaan siklus langsung sangat dimungkinkan. Parameter teras RGTT200K diberikan dalam Tabel 1.

Tabel 1. Parameter teras RGTT200K.

\begin{tabular}{|l|c|}
\hline Densitas daya $\left(\mathrm{MW} / \mathrm{m}^{3}\right)$ & 3 \\
\hline Daya bahan bakar pebble $(\mathrm{kW} /$ pebble $)$ & 0,56 \\
\hline Tinggi / Diameter teras $(\mathrm{m} / \mathrm{m})$ & $9,43 / 3$ \\
\hline Temperatur inlet teras $\left({ }^{\circ} \mathrm{C}\right)$ & 550 \\
\hline Temperatur outlet teras $\left({ }^{\circ} \mathrm{C}\right)$ & 950 \\
\hline Pendingin & $\mathrm{He}$ \\
\hline Tekanan helium $(\mathrm{MPa})$ & 5,2 \\
\hline Laju aliran massa $(\mathrm{kg} / \mathrm{s})$ & 120 \\
\hline Densitas helium $\left(\mathrm{kg} / \mathrm{m}^{3}\right)$ & 0,178 \\
\hline
\end{tabular}

RGTT200K mengadopsi desain standard bahan bakar yang dikembangkan oleh Jerman untuk HTR-Modul [9] dan HTR-10 Cina dengan geometri dan dimensi yang serupa dengan reaktor modular pebble bed (pebble bed modular reactor, PBMR) [10] Afrika Selatan. Setiap bahan bakar pebble (diameter $6 \mathrm{~cm}$ ) terdiri dari bola matriks grafit berdiameter $5 \mathrm{~cm}$ yang diisi oleh 15.000 partikel berlapis TRISO dan shell grafit yang bebas dari bahan bakar dengan ketebalan $0,5 \mathrm{~cm}$. Partikel TRISO sendiri dibentuk oleh bahan bakar kernel berdiameter $0,05 \mathrm{~cm}$ dan dikelilingi oleh lapisan karbon dengan ketebalan tipikal $0,021 \mathrm{~cm}$ yang terdiri dari buffer $0,0095 \mathrm{~cm}$, karbon pirolitik bagian dalam (inner pyrolitic carbon, $\mathrm{IPyC}) 0,0040 \mathrm{~cm}$, silikon karbida (SiC) $0,0035 \mathrm{~cm}$ dan karbon pirolitik bagian luar (outer pyrolitic carbon, OPyC) 0,0040 $\mathrm{cm}$. Lapisan buffer berfungsi menampung akumulasi gas fisi yang terbentuk dari proses fisi di dalam bahan bakar kernel sedangkan karbon pirolitik bagian dalam dan luar serta silikon karbida berfungsi sebagai lapisan penahan yang tidak dapat ditembus dan sangat efektif untuk mencegah produk fisi menyebar keluar dari partikel bahan bakar pada temperatur tinggi. Partikel TRISO dapat mempertahankan semua produk fisi hampir sepenuhnya sepanjang temperatur bahan bakar tidak melebihi $1600^{\circ} \mathrm{C}$. Dalam kasus kecelakaan terjadinya kehilangan pendingin aktif, laju probabilitas pelepasan produk fisi kurang dari $1 \times 10^{-5}$ selama beberapa ratus jam pada temperatur $1600^{\circ} \mathrm{C}$. Diagram skematik partikel TRISO dan bahan bakar pebble diperlihatkan dalam Gambar 1. 


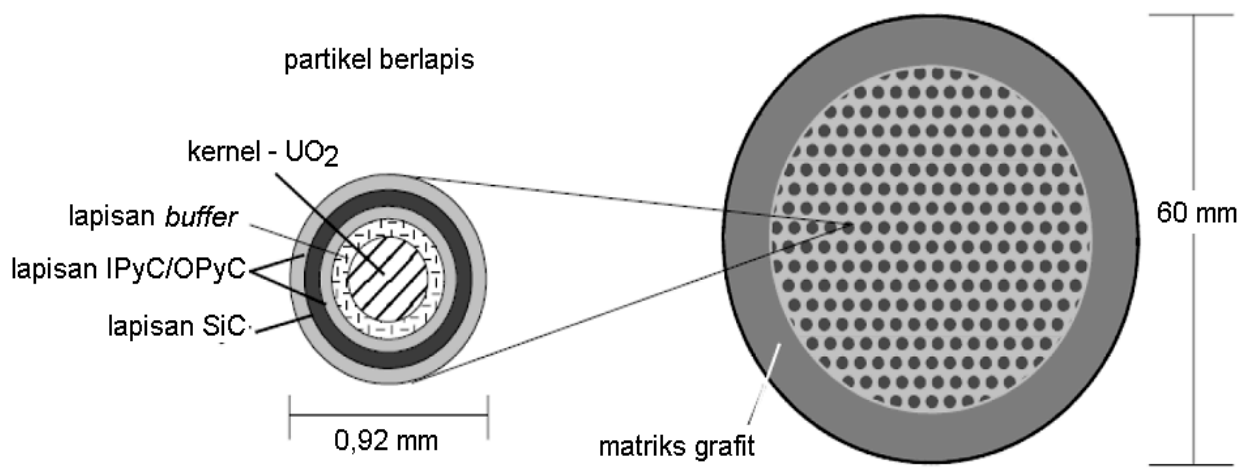

Gambar 1. Diagram skematik partikel TRISO dan bahan bakar pebble [11].

Tabel 2. Parameter desain partikel TRISO dan bahan bakar pebble.

\begin{tabular}{|l|r|l|r|}
\hline \multicolumn{2}{|c|}{ Partikel berlapis TRISO } & \multicolumn{2}{c|}{ Bahan bakar pebble } \\
\hline Komposisi kernel & $\mathrm{UO}_{2}, \mathrm{ThO}_{2} / \mathrm{UO}_{2}, \mathrm{PuO}_{2}$ & $\begin{array}{l}\text { Massa logam berat } \\
(\mathrm{g} / \text { pebble })\end{array}$ & 9,2 \\
\hline Diameter kernel, $1 \times 10^{-6}(\mathrm{~cm})$ & 500 & $\begin{array}{l}\text { Pengkayaan isotop fisil } \\
(\%)\end{array}$ & $8,2 / 7,48 / 53,85$ \\
\hline $\begin{array}{l}\text { Ketebalan lapisan coating } \\
1 \times 10^{-6}(\mathrm{~cm})\end{array}$ & $95 / 40 / 35 / 40$ & $\begin{array}{l}\text { Jumlah partikel TRISO } \\
\text { per pebble }\end{array}$ & 15.000 \\
\hline Urutan lapisan coating & Buffer/IPyC/SiC/OPyC & $\begin{array}{l}\text { Volume pemuatan } \\
\text { partikel TRISO }(\%)\end{array}$ & 5,4 \\
\hline
\end{tabular}

Dalam RGTT200K, bahan bakar pebble dimuatkan ke dalam teras dan dikeluarkan dari teras secara kontinu selama operasi reaktor. Berbagai daur bahan bakar dapat diakomodasi tanpa modifikasi desain teras yang signifikan, karena itu dalam analisis ini tiga opsi bahan bakar kernel $\mathrm{UO}_{2}, \mathrm{ThO}_{2} / \mathrm{UO}_{2}$ dan $\mathrm{PuO}_{2}$ diterapkan untuk mendapatkan komparasi kelakuan reaktivitas Doppler teras RGTT200K berbahan bakar uranium, thorium dan plutonium. Kernel $\mathrm{UO}_{2}$ dan $\mathrm{ThO}_{2} / \mathrm{UO}_{2}$ memiliki pengkayaan ${ }^{235} \mathrm{U}$ dan ${ }^{233} \mathrm{U}$ masing-masing $8,2 \%$ dan 7,48 \%. Kernel $\mathrm{PuO}_{2}$ terdiri dari beberapa isotop plutonium, yakni ${ }^{238} \mathrm{Pu} /{ }^{239} \mathrm{Pu} /{ }^{240} \mathrm{Pu} /{ }^{241} \mathrm{Pu} /{ }^{242} \mathrm{Pu}$ dengan kandungan spesifik $0,0259 / 0,5385 / 0,2366 / 0,1313 /$ 0,0677. Bahan bakar pebble dan partikel berlapis TRISO dengan kernel $\mathrm{UO}_{2}, \mathrm{ThO}_{2} / \mathrm{UO}_{2}$ dan $\mathrm{PuO}_{2}$ memiliki spesifikasi dan geometri yang sama. Parameter desainnya diberikan dalam Tabel 2.

\section{METODOLOGI}

Untuk memahami efek kecelakaan water ingress yang disebabkan oleh pecahnya tabung penukar panas generator uap, sejumlah air dengan kuantitas tertentu disimulasikan masuk ke dalam teras reaktor. Situasi water ingress akan mempengaruhi reaktivitas teras karena air sebagai moderator neutron yang baik dapat mengubah spektrum neutron. Untuk menganalisis meningkatnya moderasi karena water ingress, perhitungan reaktivitas Doppler teras RGTT200K dilakukan untuk perubahan temperatur dari $800 \mathrm{~K}$ ke $1800 \mathrm{~K}$ pada kondisi water ingress dengan densitas air dari 0 hingga 1000 $\mathrm{kg} / \mathrm{m}^{3}$.

Dalam analisis ini, reaktivitas moderator dan reflektor tidak ikut dihitung karena kontribusinya tidak begitu signifikan. Koefisien reaktivitas Doppler memiliki efek yang jauh lebih besar dan bahkan secara umum dianggap lebih penting daripada koefisien temperatur moderator dan reflektor karena dalam hal kejadian insersi reaktivitas positif yang besar, temperatur moderator dan reflektor tidak dapat mengubah kenaikan reaktivitas dalam waktu yang cepat, sedangkan koefisien reaktivitas Doppler segera beraksi secara agresif dengan menambahkan koefisien negatif untuk mengkompensasi situasi agar tetap terkendali. 
Reaktivitas Doppler teras RGTT200K ( $\alpha_{F}^{D}$ ) yang didefinisikan sebagai rasio perubahan reaktivitas $(\Delta \rho)$ dengan perubahan temperatur bahan bakar $(\Delta T)$ diperoleh dari nilai faktor multiplikasi reaktor $\left(k_{e f f}\right)$ menggunakan formula,

$\alpha_{F}^{D}=\frac{\Delta \rho}{\Delta T}=\frac{k_{e f f}^{T_{2}}-k_{e f f}^{T_{1}}}{T_{2}-T_{1}} \times \frac{1}{k_{e f f}^{T_{1}} \times k_{e f f}^{T_{2}}}$

dimana $k_{\text {eff }}^{T_{1}}$ dan $k_{\text {eff }}^{T_{2}}$ masing-masing adalah faktor multiplikasi reaktor dalam kecelakaan water ingress pada temperatur $T_{1}$ dan $T_{2}$ untuk densitas air dari 0 hingga $1000 \mathrm{~kg} / \mathrm{m}^{3}$.

Perhitungan faktor multiplikasi reaktor $\left(k_{\text {eff }}\right)$ dikerjakan dengan program transport Monte Carlo MCNPX setelah pemodelan teras RGTT200K dilakukan. Dalam memodelkan RGTT200K, MCNPX menangani problema stokastisiti ganda: dispersi stokastik partikel TRISO dalam matriks grafit dari setiap bahan bakar pebble dan distribusi stokastik dari ribuan bahan bakar pebble dalam teras reaktor. Proses pemodelan terdiri dari dua tahap, yaitu pemodelan bahan bakar pebble dan pemodelan teras.

\section{Pemodelan bahan bakar pebble}

Pada tahap awal, yang disebut pemodelan heterogenitas pertama, bahan bakar pebble dimodelkan. Pemodelan dimulai dari partikel TRISO dengan kisi kubik sederhana (simple cubic, SC). Partikel TRISO dalam matriks grafit didefinisikan MCNPX sebagai sebuah "UNIVERSE" yang diinsersikan ke dalam kisi SC dengan kartu "FILL". Pitch kisi SC ditetapkan 0,16343 cm untuk mendapatkan fraksi packing TRISO 9,3443 \%. Kombinasi kartu "LATTICE" dan "FILL" kemudian digunakan untuk menyusun 15.000 partikel TRISO dalam bahan bakar pebble. Gambar 2 memperlihatkan model MCNPX untuk partikel TRISO dan bahan bakar pebble sedangkan densitas atomnya dirangkum dalam Tabel 3.

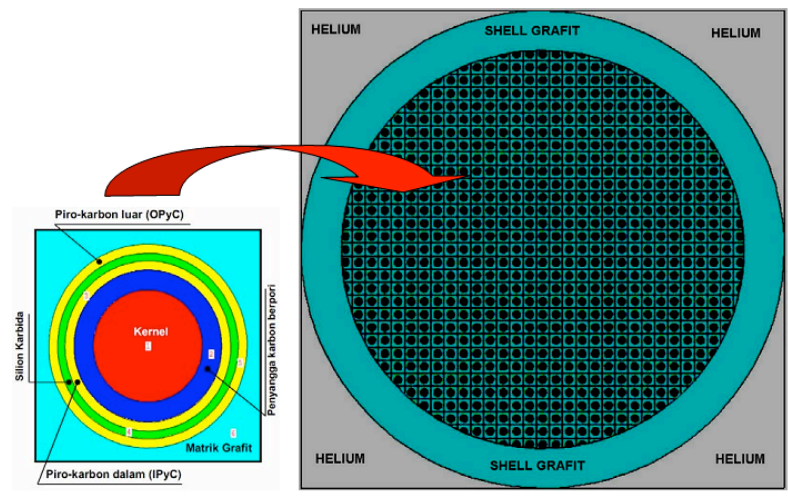

Gambar 2. Model MCNPX untuk partikel TRISO dan bahan bakar pebble.

Tabel 3. Densitas atom bahan bakar kernel dan lapisan coating.

\begin{tabular}{|c|c|c|c|c|c|}
\hline Nuklida & $\begin{array}{l}\text { Densitas } \\
\left(\mathrm{g} / \mathrm{cm}^{3}\right)\end{array}$ & $\begin{array}{c}\text { Densitas atom } \\
\left(\times 10^{24} \text { atom } / \mathrm{cm}^{3}\right)\end{array}$ & Nuklida & $\begin{array}{l}\text { Densitas } \\
\left(\mathrm{g} / \mathrm{cm}^{3}\right)\end{array}$ & $\begin{array}{c}\text { Densitas atom } \\
\left(\times 10^{24} \text { atom } / \mathrm{cm}^{3}\right)\end{array}$ \\
\hline \multicolumn{3}{|c|}{ Kernel $\mathrm{UO}_{2}$} & \multicolumn{3}{|c|}{ Kernel $\mathrm{ThO}_{2} / \mathrm{UO}_{2}$} \\
\hline${ }^{238} \mathrm{U}$ & \multirow{5}{*}{10,4} & $2,12877 \times 10^{-2}$ & ${ }^{232} \mathrm{Th}$ & \multirow{5}{*}{10,4} & $2,19473 \times 10^{-2}$ \\
\hline${ }^{235} \mathrm{U}$ & & $1,92585 \times 10^{-3}$ & ${ }^{233} \mathrm{U}$ & & $1,76668 \times 10^{-3}$ \\
\hline${ }^{16} \mathrm{O}$ & & $4,64272 \times 10^{-2}$ & ${ }^{16} \mathrm{O}$ & & $4,74279 \times 10^{-2}$ \\
\hline${ }^{10} \mathrm{~B}$ & & $1,14694 \times 10^{-7}$ & ${ }^{10} \mathrm{~B}$ & & $1,14694 \times 10^{-7}$ \\
\hline${ }^{11} \mathrm{~B}$ & & $4,64570 \times 10^{-7}$ & ${ }^{111} \mathrm{~B}$ & & $4,64570 \times 10^{-7}$ \\
\hline \multicolumn{3}{|c|}{ Kernel $\mathrm{PuO}_{2}$} & \multicolumn{3}{|c|}{ Buffer } \\
\hline${ }^{238} \mathrm{Pu}$ & & $6,01178 \times 10^{-4}$ & ${ }^{12} \mathrm{C}$ & 1,05 & $5,26449 \times 10^{-2}$ \\
\hline${ }^{239} \mathrm{Pu}$ & & $1,24470 \times 10^{-2}$ & \multicolumn{3}{|c|}{$\mathrm{IPyC}$} \\
\hline
\end{tabular}




\begin{tabular}{|c|c|c|c|c|c|}
\hline Nuklida & $\begin{array}{c}\text { Densitas } \\
\left(\mathrm{g} / \mathrm{cm}^{3}\right)\end{array}$ & $\begin{array}{c}\text { Densitas atom } \\
\left(\times 10^{24} \text { atom } / \mathrm{cm}^{3}\right)\end{array}$ & Nuklida & $\begin{array}{c}\text { Densitas } \\
\left(\mathrm{g} / \mathrm{cm}^{3}\right)\end{array}$ & $\begin{array}{c}\text { Densitas atom } \\
\left(\times 10^{24} \text { atom } / \mathrm{cm}^{3}\right)\end{array}$ \\
\hline${ }^{240} \mathrm{Pu}$ & & $5,44599 \times 10^{-3}$ & ${ }^{12} \mathrm{C}$ & 1,90 & $9,52621 \times 10^{-2}$ \\
\hline${ }^{241} \mathrm{Pu}$ & & $3,00965 \times 10^{-3}$ & \multicolumn{3}{|c|}{$\mathrm{SiC}$} \\
\hline${ }^{242} \mathrm{Pu}$ & & $1,54539 \times 10^{-3}$ & Si-nat & \multirow[b]{2}{*}{3,19} & $4,77240 \times 10^{-2}$ \\
\hline${ }^{16} \mathrm{O}$ & & $4,60983 \times 10^{-2}$ & ${ }^{12} \mathrm{C}$ & & $4,77240 \times 10^{-2}$ \\
\hline${ }^{10} \mathrm{~B}$ & & $1,14694 \times 10^{-7}$ & \multicolumn{3}{|c|}{ OPyC } \\
\hline${ }^{11} \mathrm{~B}$ & & $4,64570 \times 10^{-7}$ & ${ }^{12} \mathrm{C}$ & 1,90 & $9,52621 \times 10^{-2}$ \\
\hline
\end{tabular}

\section{Pemodelan teras}

Pada tahap berikutnya, yang disebut pemodelan heterogenitas kedua, teras RGTT200K dimodelkan. Lokasi bahan bakar pebble ditentukan dengan tiga model kisi, yaitu face centered cubic (FCC), body centered cubic (BCC) dan SC dengan fraksi packing maksimal masing-masing $74 \%, 68$ \% dan $52 \%$. Fitur "LIKE n BUT" dan kartu "TRCL" dimanfaatkan untuk transformasi spasial bahan bakar pebble khususnya untuk kisi FCC dan BCC. Bahan bakar pebble bersama helium di antara pebble didefinisikan MCNPX sebagai sebuah "UNIVERSE" yang diinsersikan ke dalam kisi dengan kartu "FILL". Pitch kisi ditetapkan sesuai dengan fraksi packing pebble yang dipilih seperti diberikan dalam Tabel 4. Serupa dengan pemodelan bahan bakar pebble, kombinasi kartu "LATTICE" dan "FILL" kemudian digunakan untuk menyusun 359.548 bahan bakar pebble dalam teras reaktor.

Tabel 4. Fraksi packing pebble dan pitch kisi.

\begin{tabular}{|c|c|c|}
\hline Kisi & Fraksi packing $(\%)$ & Pitch kisi $(\mathrm{cm})$ \\
\hline SC & 52 & 6 \\
\hline BCC & 68 & 6,928203 \\
\hline FC & 74 & 8,485281 \\
\hline BCC & 61 (tipikal) & 7,185259 \\
\hline
\end{tabular}

Pemodelan struktur teras lainnya, seperti reflektor dan lain-lain merupakan bagian termudah dalam pemodelan teras dengan fitur kisi MCNPX. Pemodelan konus di bagian bawah teras yang hanya ditempati oleh moderator pebble memerlukan penanganan yang serupa dengan bahan bakar pebble di dalam teras. Fraksi packing tipikal dari kisi BCC digunakan untuk memodelkan moderator pebble di dalam konus. Gambar 3 memperlihatkan model MCNPX untuk teras RGTT200K.

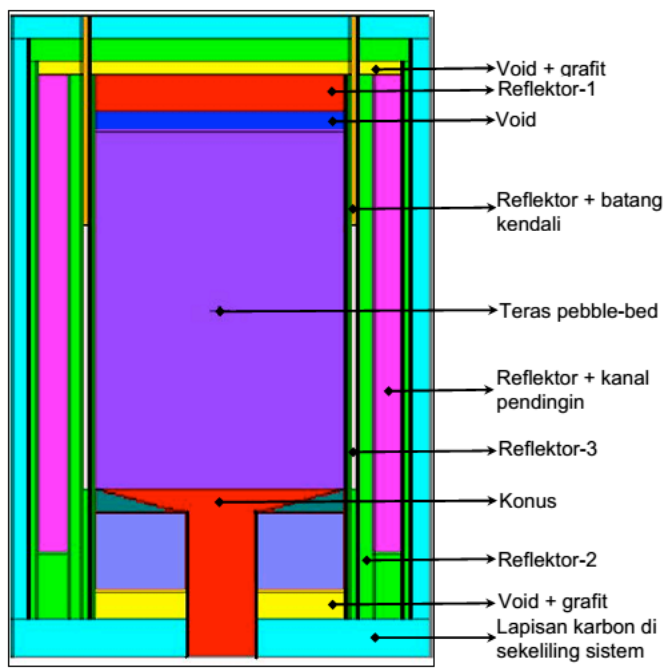

Gambar 3. Model MCNPX untuk teras RGTT200K. 


\section{HASIL PERHITUNGAN DAN DISKUSI}

Efek kecelakaan water ingress terhadap koefisien reaktivitas Doppler teras uranium RGTT200K dilukiskan dalam Gambar 4 untuk tiga model kisi. Kurva ini mengilustrasikan masuknya air ke dalam teras menghasilkan koefisien reaktivitas Doppler yang berkurang untuk semua model kisi yang dipertimbangkan. Penurunan koefisien Doppler tidak lagi fantastis di atas $500 \mathrm{~kg} / \mathrm{m}^{3}$ karena terlalu banyak neutron yang ditangkap oleh air. Dalam hal ini sifat air berubah fungsi dari termalisasi spektrum menjadi racun neutron karena absorpsinya yang tinggi. Jika Gambar 4 diamati lebih jauh, efek water ingress nampak lebih kuat pada model kisi dengan fraksi packing lebih rendah. Hal ini karena dengan faktor packing yang lebih rendah lebih banyak volume yang tersedia untuk air yang memasuki teras reaktor. Koefisien Doppler berkurang $5,132 \times 10^{-5} \Delta \mathrm{k} / \mathrm{k} \mathrm{K}^{-1} ; 4,288 \times 10^{-5} \Delta \mathrm{k} / \mathrm{k} \mathrm{K}^{-1}$ dan $3,173 \times 10^{-5} \Delta \mathrm{k} / \mathrm{k} \mathrm{K}^{-1}$ masing-masing untuk kisi SC, BCC dan FCC pada kondisi water ingress dengan densitas air paling besar yang ekivalen dengan massa air $26.000 \mathrm{~kg}$. Menurut Yanhua [12], nilai ini tidak mungkin terjadi karena jumlah air maksimum yang bisa memasuki teras dalam kondisi water ingress tidak lebih dari $4.000 \mathrm{~kg}$, namun dalam analisis ini perhitungan dilakukan hingga kondisi yang paling ekstrim.

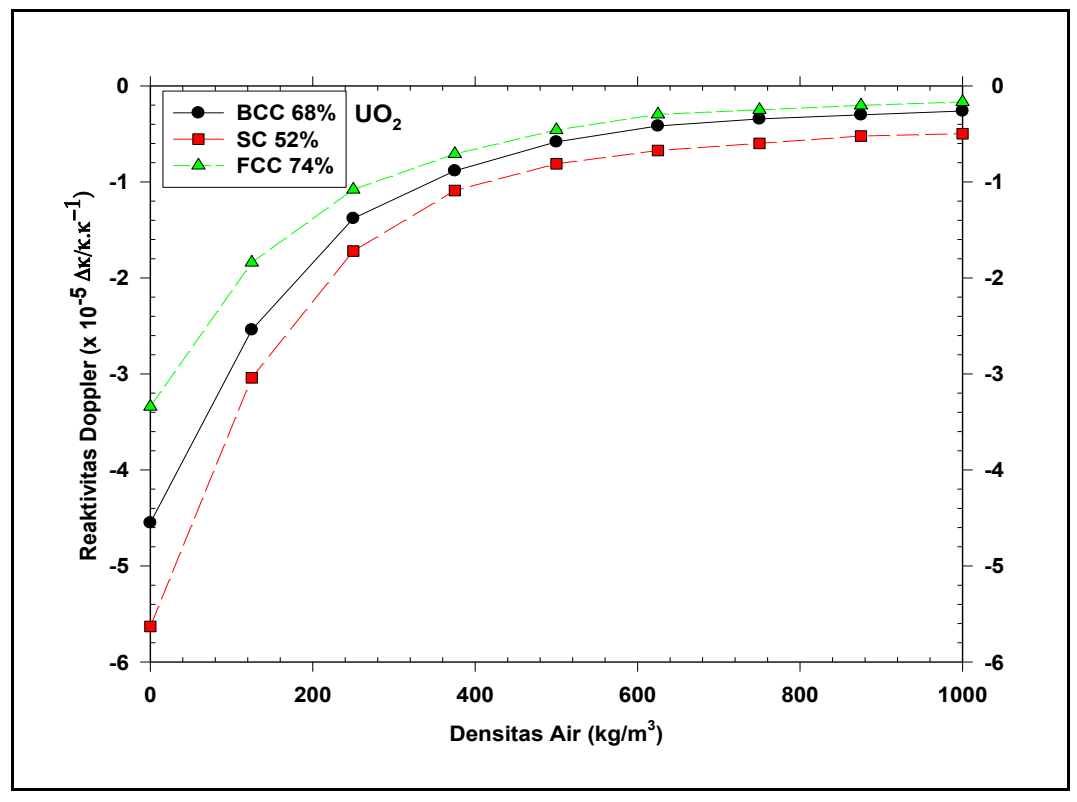

Gambar 4. Efek water ingress terhadap reaktivitas Doppler teras uranium RGTT200K.

Efek kecelakaan water ingress terhadap koefisien reaktivitas Doppler teras thorium dan plutonium RGTT200K dilukiskan dalam Gambar 5 dan 6 yang memperlihatkan kelakuan tidak banyak berubah. Penurunan koefisien Doppler tidak lagi tajam di atas densitas $500 \mathrm{~kg} / \mathrm{m}^{3}$, namun efek water ingress tetap nampak lebih kuat pada model kisi dengan fraksi packing lebih rendah sebagai akibat dari fraksi volume pendingin yang lebih besar yang dimasuki air. Kondisi water ingress dengan densitas air paling besar menghasilkan koefisien Doppler teras thorium berkurang $2,401 \times 10^{-5} \Delta \mathrm{k} / \mathrm{k} \mathrm{K}^{-1} ; 2,106 \times 10^{-5}$ $\Delta \mathrm{k} / \mathrm{k} \mathrm{K}^{-1}$ dan $8,530 \times 10^{-6} \Delta \mathrm{k} / \mathrm{k} \mathrm{K}^{-1}$ sedangkan koefisien Doppler teras plutonium berkurang $1,581 \times 10^{-5}$ $\Delta \mathrm{k} / \mathrm{k} \mathrm{K}^{-1} ; 1,496 \times 10^{-5} \Delta \mathrm{k} / \mathrm{k} \mathrm{K}^{-1}$ dan $1,279 \times 10^{-5} \Delta \mathrm{k} / \mathrm{k} \mathrm{K}^{-1}$ masing-masing untuk kisi SC, BCC dan FCC. 


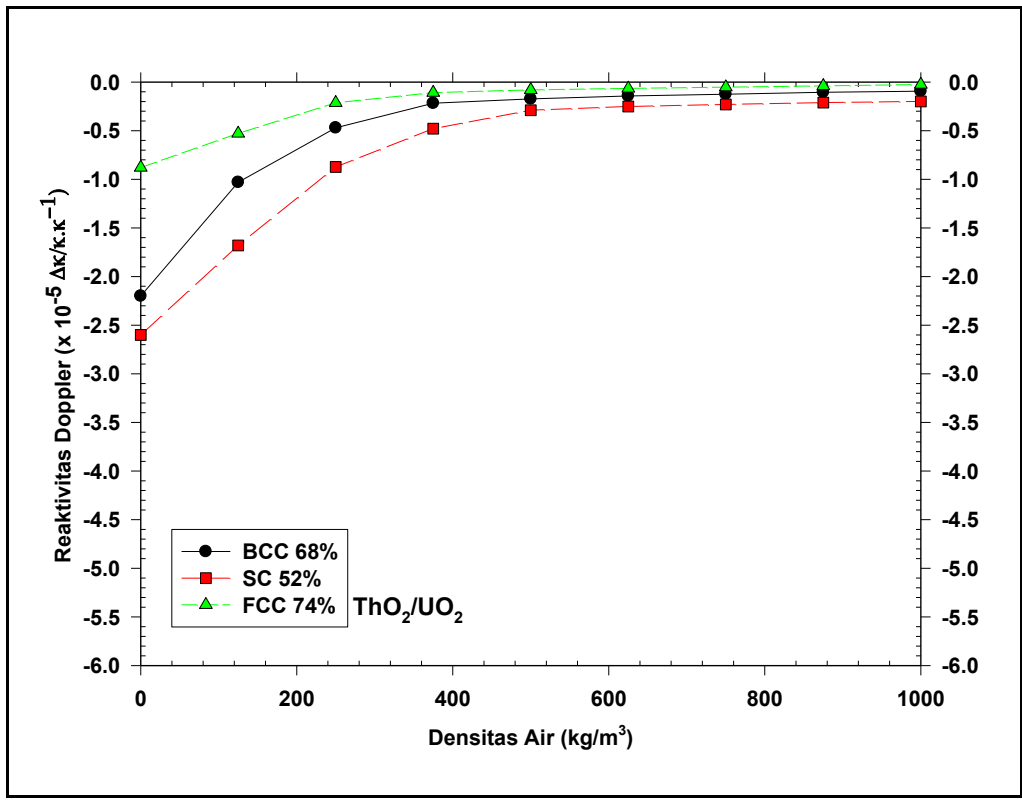

Gambar 5. Efek water ingress terhadap reaktivitas Doppler teras thorium RGTT200K.

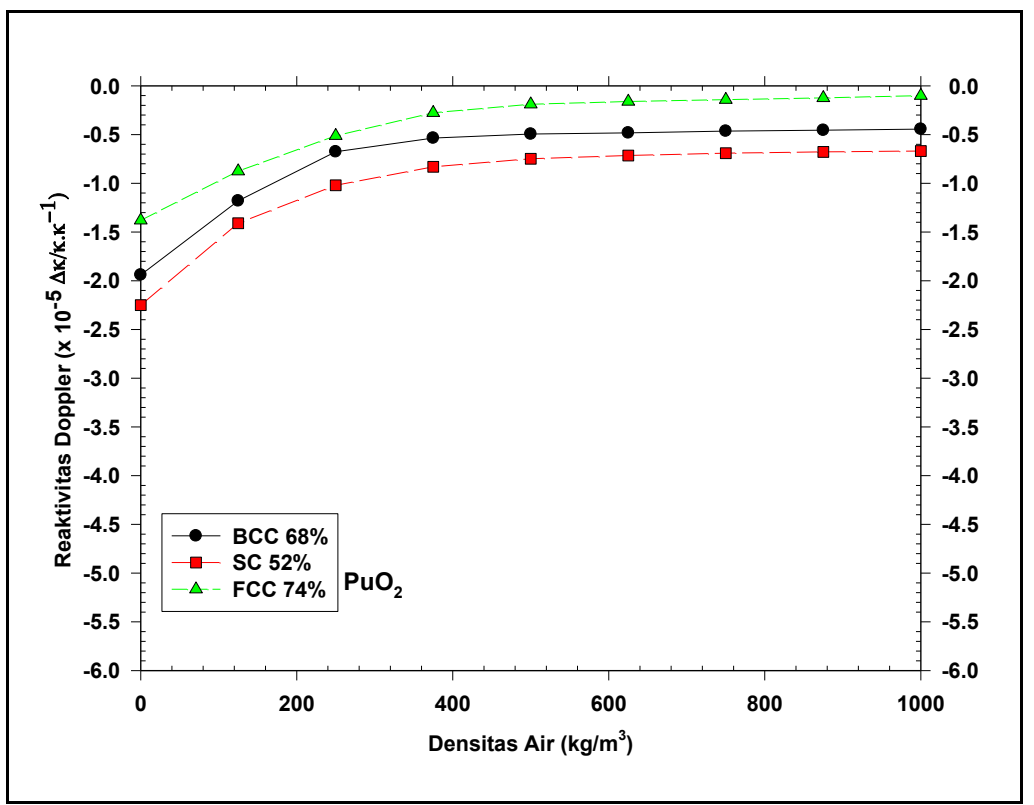

Gambar 6. Efek water ingress terhadap reaktivitas Doppler teras plutonium RGTT200K.

Komparasi koefisien reaktivitas Doppler teras uranium, thorium dan plutonium RGTT200K sebagai efek kecelakaan water ingress dilukiskan dalam Gambar 7 untuk model kisi BCC tipikal. Kisi BCC dengan fraksi packing tipikal $61 \%$ acapkali dipilih untuk memodelkan distribusi bahan bakar pebble di teras reaktor pebble bed. Gambar ini mengilustrasikan ketika temperatur meningkat, koefisien reaktivitas Doppler tetap negatif untuk seluruh opsi bahan bakar yang diterapkan bahkan untuk posibilitas water ingress yang besar. Absorpsi neutron yang tinggi dari air menjadi penyebab mengapa koefisien reaktivitas Doppler selalu negatif. Dari Gambar 7 dapat diamati pula efek Doppler uranium nampak lebih dominan dibandingkan efek Doppler thorium dan plutonium dimana koefisien Doppler teras thorium dan plutonium masing-masing berkurang $1,458 \times 10^{-5} \Delta \mathrm{k} / \mathrm{k} \mathrm{K}^{-1}$ dan $1,894 \times 10^{-5}$ $\Delta \mathrm{k} / \mathrm{k} \mathrm{K}^{-1}$. Nilai-nilai ini lebih kecil daripada $4,665 \times 10^{-5} \Delta \mathrm{k} / \mathrm{k} \mathrm{K}^{-1}$ ketika bahan bakar RGTT200K berganti dari $\mathrm{UO}_{2}$ menjadi $\mathrm{ThO}_{2} / \mathrm{UO}_{2}$ dan $\mathrm{PuO}_{2}$. Konsekuensi dari fenomena Doppler dimana absorpsi neutron di daerah resonansi ${ }^{238} \mathrm{U}$ lebih besar daripada ${ }^{232} \mathrm{Th}$ dan ${ }^{240} \mathrm{Pu}$ menjadi alasan mengapa efek water ingress lebih kuat di teras uranium daripada teras thorium dan plutonium. 


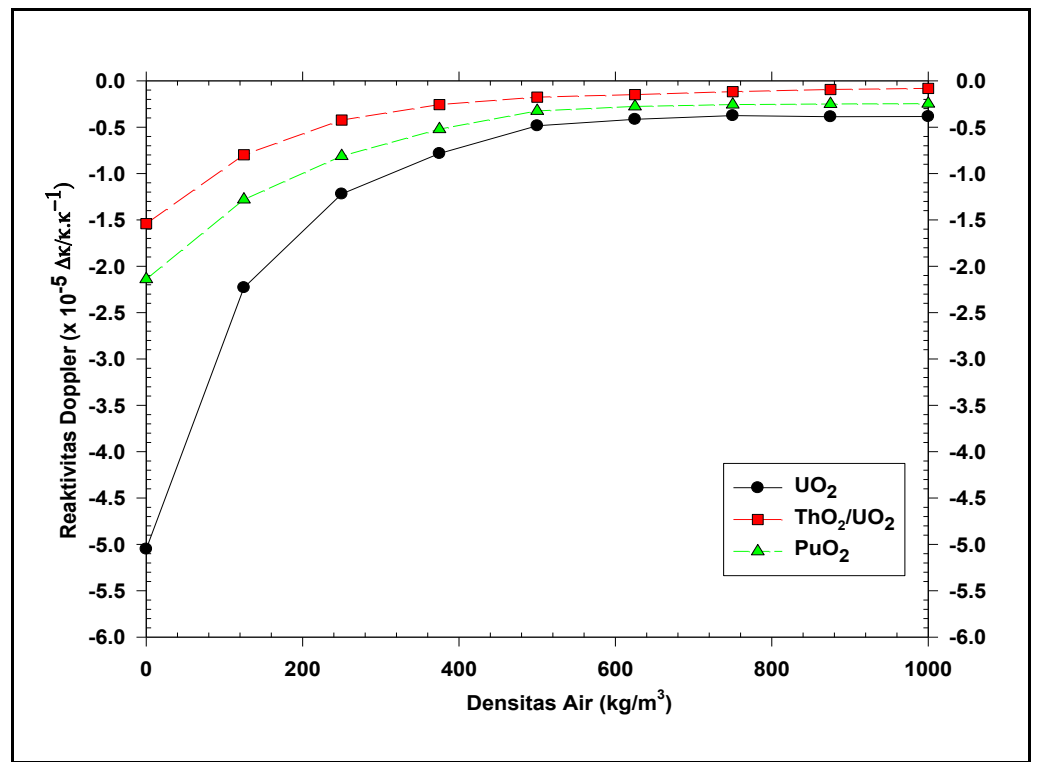

Gambar 7. Efek water ingress terhadap reaktivitas Doppler teras uranium, thorium dan plutonium RGTT200K.

Secara keseluruhan dapat dikatakan bahwa, kenaikan reaktivitas karena efek water ingress dapat dikompensasi oleh koefisien reaktivitas Doppler teras RGTT200K. Jika penurunan koefisien reaktivitas Doppler dari $800 \mathrm{~K}$ ke $1800 \mathrm{~K}$ tidak cukup besar untuk mengkompensasi insersi reaktivitas dalam kondisi water ingress, ini berarti kenaikan reaktivitas tidak dapat diimbangi oleh sifat keselamatan melekat yang dimiliki reaktor dan karenanya bergantung pada mekanisme keselamatan aktif lainnya seperti batang kendali. Dalam HTR yang aman, koefisien reaktivitas temperatur dari setiap masuknya air harus bernilai negatif. Jika kondisi ini tidak tercapai, komposisi bahan bakar pebble seperti pemuatan logam berat (heavy metal) dan pengkayaan bahan bakar harus diubah agar dapat menghasilkan respons reaktivitas negatif yang diperlukan untuk mengantisipasi kecelakaan water ingress.

Namun demikian, walaupun koefisien reaktivitas Doppler dapat mengkompensasi reaktivitas positif yang diakibatkan kecelakaan water ingress, potensi bahaya lainnya seperti uap air yang bersama grafit panas bereaksi menjadi gas hidrogen tidak dapat diabaikan selain korosi grafit. Insiden kecelakaan water ingress di Arbeitsgemeinschaft Versuchsreaktor (AVR)[13] tahun 1978 yang ternyata tidak menyebabkan ekskursi reaktivitas, tidak menyurutkan prioritas yang harus diberikan kepada solusi problema keselamatan yang berkaitan dengan operasi dan kecelakaan dasar desain water ingress. Memanfaatkan lapisan tipis $\mathrm{SiC}$ pada permukaan bahan bakar pebble merupakan salah satu konsep untuk mengurangi dampak akibat kecelakaan water ingress yang banyak mendapat perhatian fisikawan reaktor temperatur tinggi.

\section{KESIMPULAN}

Analisis efek kecelakaan water ingress terhadap reaktivitas Doppler teras RGTT200K telah dilakukan dengan memanfaatkan program transport Monte Carlo MCNPX dan pustaka data nuklir energi kontinu ENDF/B-VII untuk perubahan temperatur bahan bakar dari $800 \mathrm{~K}$ hingga 1800K. Tiga opsi kernel bahan bakar $\mathrm{UO}_{2}, \mathrm{ThO}_{2} / \mathrm{UO}_{2}$ dan $\mathrm{PuO}_{2}$ dengan tiga model kisi bahan bakar pebble di teras reaktor diterapkan untuk kondisi water ingress dengan densitas air dari 0 hingga $1000 \mathrm{~kg} / \mathrm{m}^{3}$.

Koefisien reaktivitas Doppler tetap negatif untuk seluruh opsi bahan bakar yang dipertimbangkan dalam teras RGTT200K bahkan untuk posibilitas water ingress yang besar. Efek water ingress lebih kuat pada model kisi dengan fraksi packing lebih rendah karena lebih banyak volume yang tersedia untuk air yang memasuki teras reaktor. Efek water ingress juga lebih kuat di teras uranium dibandingkan teras thorium dan plutonium sebagai konsekuensi dari fenomena Doppler dimana absorpsi neutron di daerah resonansi ${ }^{238} \mathrm{U}$ lebih besar daripada ${ }^{232} \mathrm{Th}$ dan ${ }^{240} \mathrm{Pu}$. 
Dari analisis dapat disimpulkan bahwa, koefisien Doppler teras RGTT200K mampu mengkompensasi insersi reaktivitas yang diintroduksi oleh kecelakaan water ingress. Teras RGTT200K dengan bahan bakar $\mathrm{UO}_{2}, \mathrm{ThO}_{2} / \mathrm{UO}_{2}$ dan $\mathrm{PuO}_{2}$ dapat mempertahankan fitur keselamatan melekat (inherently safety).

\section{UCAPAN TERIMAKASIH}

Ucapan terimakasih kami sampaikan kepada Ir. Tagor M. Sembiring dan Dr. Geni Rina Sunaryo, M.Sc. yang memberikan inspirasi dan motivasi dalam riset ini. Diskusi dan koreksi dari Prof. Surian Pinem, M.Sc. dan Ir. Iman Kuntoro, APU serta rekan-rekan di Bidang Fisika dan Teknologi Reaktor sangat kami hargai.

\section{DAFTAR PUSTAKA}

1. Andreas van Wijk, "Computational Modeling of the Flow Field in a Molten Salt Reactor Core", Bachelor Thesis, Delft University of Technology, June 22, 2008.

2. John E. Kelly, "Generation IV International Forum: A Decade of Progress through International Cooperation", Progress in Nuclear Energy, Volume 77, pages 240-246, November 2014.

3. Kazuhiko Kunitomi, "R\&D on High-Temperature Gas-Cooled Reactor technology Utilizing Japan's HTTR”, Journal of Nuclear Science and Technology, Vol. 51, No. 11-12, 2014.

4. Chen Yang, Chao Fang, Jianzhu Cao, "The Design and Thermohydraulics Study of the HTR10 High Temperature Helium Experimental Loop", Progress in Nuclear Energy, Volume 77, Pages 329-335, November 2014.

5. Zuhair, Suwoto, "Analisis Perhitungan Koefisien Reaktivitas Bahan Bakar dan Moderator Teras RGTT200K”, Prosiding Seminar Nasional Sains dan Teknologi Nuklir, Bandung, 4 Juli 2013.

6. Zuhair, Suwoto, Sumijanto, "Analisis Reaktivitas Teras RGTT200K dalam Skenario Kecelakaan Water Ingress", Prosiding ke Seminar Nasional Ke-19 Teknologi dan Keselamatan PLTN serta Fasilitas Nuklir, Yogyakarta, 24 September 2013.

7. M.L. Fensin, J.S. Hendricks, S. Anghaie, "The Enhancements and Testing for the MCNPX 2.6.0 Depletion Capability", Journal of Nuclear Technology, Volume 170, pages 68-79, April 2010.

8. M. Herman, "Development of ENDF/B-VII and Its Covariance Component", Journal of the Korean Physical Society, Vol. 59, No. 2, pages 1034-1039, August 2011.

9. Gerhard Strydom, Hans D. Gougar, "Preliminary Reactor Physics Assessment of the HTR Module with 14\% Enriched UCO Fuel", Nuclear Engineering and Design, Volume 256, pages 304-321, March 2013.

10. Trevor Dudley, et al., "The Reactor Core Neutronic Model for the Pebble Bed Modular Reactor", Journal of Nuclear Engineering and Design, 238, pages 3002-3012, 2008.

11. S.K. Gintner, "Thorium-based Fuel Cycles: Saving Uranium in a 200 MWth Pebble Bed High Temperature Reactor", North West University, Master of Engineering Thesis, October 27, 2010.

12. Z. Yanhua, S. Lei, W. Yan, "Water-ingress Analysis for the 200MWe Pebble-bed Modular High Temperature Gas-cooled Reactor", Nuclear Engineering and Design 240, pages 30953107, 2010.

13. Rainer Moormann, "Fission Product Transport and Source Terms in HTRs: Experience from AVR Pebble Bed Reactor", Journal of Science and Technology of Nuclear Installations, Volume 2008, Article ID 597491, 2008. 